\title{
Positive Impact of Physical Exercise for Managing Stereotypies in Dogs
}

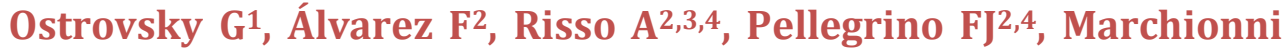 \\ $\mathbf{M}^{2}$, Aversa $\mathrm{D}^{2}$ and Corrada $\mathrm{Y}^{2,4 *}$ \\ ${ }^{1}$ Consultorio de Etología, Hospital Escuela, Facultad de Ciencias Veterinarias (FCV), \\ Universidad Nacional de La Plata (UNLP), Argentina \\ ${ }^{2}$ Laboratorio de Fisioterapia Veterinaria - Lafivet, FCV-UNLP, Argentina \\ ${ }^{3}$ Instituto de Genética Veterinaria (IGEVET), FCV-UNLP, Argentina \\ ${ }^{4}$ Consejo Nacional de Investigaciones Científicas y Técnicas (CONICET), Argentina
}

\section{Case Report}

Volume 2 Issue 5

Received Date: November 08, 2017

Published Date: December 14, 2017

Corresponding author: Corrada Y, Consejo Nacional de Investigaciones Científicas y Técnicas (CONICET), La Plata, Argentina Email: Argentinay.corrada@gmail.com

\section{Abstract}

Stereotypies in dogs are repetitive behavioral patterns that occur always in the same sequence but do not play any role. This altered behavior may thus take over the animal's life, changing its sleep patterns and eating habits. The drive to adopt the specific behavior becomes increasingly stronger, to the extent that the animal may sometimes even mutilate parts of its own body, such as the tail and limbs. The overall approach to the problem through retraining of owners, environmental modification and enrichment and proper use of psychotropics proved necessary for restoring the patients' balance. However, it was also necessary to introduce a physical exercise routine with a canine motorized treadmill and/or daily walks. Although exercise itself may contribute to increased anxiety in the animal, the potential benefits justify considering its introduction for managing dogs with stereotypies

Keywords: Physical Exercise; Stereotypy; Dog

\section{Clinical Case}

Stereotypies in dogs are repetitive behavioral patterns that occur always in the same sequence but do not play any role. This altered behavior may thus take over the animal's life, changing its sleep patterns and eating habits. The drive to adopt the specific behavior becomes increasingly stronger, to the extent that the animal may sometimes even mutilate parts of its own body, such as the tail and limbs [1].

At the ethology clinic of the University Hospital of the School of Veterinary Sciences in La Plata there arrived two female dogs, one greyhound $(\mathrm{n}=1)$ and one mixedbreed $(n=1)$. The complaint was similar in both cases, as the owners reported behavioral changes in their dogs that had been in progress for some time then, even to the point 
of starting to chase them and compulsively biting their own tails. The female greyhound's medical history included significant background of previous abuse, leading to the dog's adoption by a new owner, with whom it gradually developed hyper-attachment, anxiety and stereotypes. The mixed-breed female had also undergone a change of owners, because the previous one had traveled abroad, leaving the dog with continually rotating students, which contributed to increasing the dog's anxiety.

\section{Physical Examination and Diagnosis}

During the visit to the ethologyclinic, both animals were psychically unstable, and it was very difficult to keep them still and relaxed. Upon clinical examination, the greyhound showed amputation of the anterior right limb resulting from serious fractures suffered with its previous owner. Both dogs had injuries in their tails due to selfmutilation, which required surgical amputation, and were therefore forced to wear basket muzzles onan ongoing basis. They were submitted to a neurological assessment to rule out any disorder, spine X-ray, and blood cell count and chemistry panel, obtaining no abnormal results. The greyhound's diagnosis was intraspecific aggression, separation anxiety and compulsive disorder due to ongoing anxiety, while the mixed-breed female's diagnosis was compulsive disorder and separation anxiety.

\section{Treatment and Evolution}

In both cases, the treatment plan included an environment modification process with owner retraining and environmental enrichment, together with drug therapy with fluoxetine $1 \mathrm{mg} / \mathrm{kg}$ every 24 hours [2].

After 4 weeks, although some improvement had been achieved as to decreased anxiety, it was not sufficient for completely eliminating the stereotyped behavior, to the extent that the greyhound mutilated itself again in a moment of owner's oversight, while the other female occasionally continued with its stereotyped tail-chasing behavior.

Therefore, an exercise routine of moderate intensity was introduced with the cooperation of the School's Physical Therapy Lab (LAFIVET). The mixed-breed female was subjected to an exercise routine on a canine motorized treadmill (Doble XX) twice a week for half an hour at a gradually increasing speed of up to $10 \mathrm{~km} / \mathrm{h}$, while the greyhound, due to one missing limb, was submitted to equivalent intensive daily walks [3-5].
Two weeks after the introduction of an exercise routine together with medication and environmental enrichment, a sufficiently balanced behavior was achieved in both female dogs, enabling withdrawal of the muzzle with no risk of further self-mutilation. At three months under this same treatment with no recurrence, they were clinically discharged, with indication to follow the treatment without interruption.

\section{Conclusions}

The overall approach to the problem through retraining of owners, environmental modification and enrichment and proper use of psychotropics proved necessary for restoring the patients' balance. However, it was also necessary to introduce a physical exercise routine with a canine motorized treadmill and/or daily walks. Although exercise itself may contribute to increased anxiety in the animal, the potential benefits justify considering its introduction for managing dogs with stereotypies.

\section{References}

1. Luescher A (2000) Compulsive behavior in companion animals. En: Houpt KA, (Ed.). Recent Advances in Companion Animal Behavior Problems. Nueva York: International Veterinary Information Service 1-6.

2. Irimajiri M, Luescher A, Douglass G, Robertson-Plouch C, Zimmermann A, et al. (2009) Randomized, controlled clinical trial of the efficacy of fluoxetine for treatment of compulsive disorders in dogs. JAVMA 235(6): 705-709.

3. Corrada Y (2016) Evolución de la Fisioterapia y Rehabilitación. En: Fisioterapia y Rehabilitación en la Clínica de Caninos. Corrada Y (ed). $1^{\text {st }}$ editión. Editorial Creadores Argentinos, Ciudad Autónoma de Buenos Aires. 15-26.

4. Corrada Y, Rochero OJ, Álvarez FG. Métodos de Fisioterapiay Rehabilitación. En: Fisioterapia y Rehabilitación en la Clínica de Caninos. Corrada Y (ed). $1^{\text {st }}$ editión. 2016: 27-42.

5. Pellegrino FJ (2016) Rehabilitación Asistida en Cinta Trotadora e Hidroterapia. En: Fisioterapia y Rehabilitación en la Clínica de Caninos. Corrada Y (ed). $1^{\text {st }}$ editión. Editorial Creadores Argentinos, Ciudad Autónoma de Buenos Aires 111-125. 